\title{
PERAN PEMERINTAH DESA DALAM PENGELOLAAN PROGRAM USAHA PENGELOLAAN PUPUK ORGANIK (UPPO) DI DESA KOLAI KECAMATAN MALUA KABUPATEN ENREKANG
}

\author{
Ariyawan Al Fayed Martmono ${ }^{1}$, Mappamiring ${ }^{1}$, Ihyani Malik ${ }^{2}$ \\ ${ }^{1}$ Program Studi Ilmu Pemerintahan Fakultas Ilmu Sosial Dan Ilmu Politik \\ Universitas Muhammadyah Makassar \\ ${ }^{2}$ Program Studi Ilmu Administrasi Negara Fakultas Ilmu Sosial Dan Ilmu Politik \\ Universitas Muhammadyah Makassar \\ Jl. Sultan Alaudin No. 259 Makassar 90221 \\ Tlp. 0411-866972 ext. 107. Fax. 0411-8655888
}

\begin{abstract}
This study aimed to determine the role of the sub-district government in managing the UPPO program. The results of this study were expected as the input for the Kolai sub-district government in performing their duties and functions as the spearhead of Indonesian government. Academically, the results of this study were expected to provide more values which can then be compared with other scientific research, particularly the study under the problem of the role of sub-district government. This was a descriptive quantitative research, basically, this was a survey study and samples in this study were 35 people by purposive sampling technique. Data were collected by using techniques such as observation, questionnaires and developed interviews for the respondent. The data were analyzed by descriptive quantitatively, in which all the data collected by the authors, and then presented in the form of frequency tabulation completed by the responds of respondents obtained from informants, interviews, and questionnaires. The results showed an active role of sub-district government in managing UPPO program that can influence the community participation in UPPO management. By the support and assist of the sub-district government, UPPO management program can run well. Moreover, the support and assist of the sub-district government towards UPPO program management were 1. Facilitate the UPPO program 2. Facilitate meetings between the representatives agricultural services and society as of manager UPPO program 3 . Carrying out training .
\end{abstract}

Keywords : village governance, UPPO management 


\section{ABSTRAK}

Penelitian ini bertujuan untuk mengetahui peranan pemerintah desa dalam pengelolaan program UPPO. Hasil dari penelitian ini diharapkan menjadi masukan bagi pemerintah desa kolai dalam menjalankan tugas dan fungsinya sebagai ujung tombak pemerintahan Indonesia. Dari segi akademik, hasil dari penelitian ini diharapkan memberi nilai tambah yang selanjutnya dapat dikomparasikan dengan penelitian-penelitian ilmiah lainnya, khususnya yang mengkaji masalah peranan pemerintah desa. Penelitian ini adalah Deskriptif kuantitatif, dasar penelitian yang digunakan adalah survey dan sampel dalam penelitian ini sebanyak 35 orang menggunakan teknik purposive sampling. Data dikumpulkan dengan menggunakan teknik berupa observasi, kuesioner serta dikembangkan dengan wawancara kepada responden. Data tersebut dianalisis secara Deskriptip kuantitatif yaitu menganalisis semua data yang berhasil dikumpulkan penulis, dan selanjutnya disajikan dalam bentuk tabulasi frekuensi dilengkapi dengan tanggapan responden yang diperoleh dari hasil Informan, wawancara, dan kuesioner. Dari hasil penelitian menunjukkan peran aktif aparat pemerintah desa dalam pengelolaaan program UPPO dapat berpengaruh terhadap partisipasi masyarakat dalam pengelolaan UPPO. Dengan adanya dukungan dan bantuan dari pemerintah desa maka pengelolaan program UPPO dapat berjalan lancar. Adapun bentuk dukungan dan bantuan pemerintah desa dalam pengelolaan program UPPO adalah (1). Memfasilitasi pengadaan program UPPO (2). Memfasilitasi pertemuan utusan dinas pertanian dengan msyarakat pengelola program UPPO (3). Melakukan pembinaan.

Kata Kunci : pemerintah desa, pengelolaan UPPO

\section{A. PENDAHULUAN}

Undang-undang Nomor 25 Tahun 2004 tentang Sistem Perencanaan Pembangunan Nasional (SPPN) merupakan salah satu upaya yang sistematis dalam rangka menghadapi perubahan kondisi sosial, ekonomi dan politik yang sangat fundamental, karena hal tersebut menuntut perlunya suatu sistem perencanaan pembangunan yang komprehensif dan mengarah kepada perwujudan transparansi, akuntabilitas, demokratisasi, desentralisasi, dan partisipasi masyarakat, yang akhirnya dapat menjamin pemanfaatan dan pengalokasian sumber dana pembangunan yang semakin terbatas menjadi lebih efisien dan efektif serta berkelanjutan. Dalam sistem tersebut, tahapan perencanaan pembangunan terdiri dari 4 (empat) tahapan, yaitu: 1 . Penyusunan rencana, 2. Penetapan rencana, 3. Pengendalian pelaksanaan rencana, 4. Evaluasi pelaksanaan rencana.
Dengan ditetapkannya Peraturan Pemerintah Nomor 72 Tahun 2005 tentang Pemerintahan Desa, maka yang dimaksud dengan Desa adalah Desa atau yang disebut dengan nama lain, selanjutnya disebut desa, adalah kesatuan masyarakat hukum yang memiliki batas-batas wilayah yang berwenang untuk mengatur dan mengurus kepentingan masyarakat setempat, berdasarkan asal-usul dan adat istiadat setempat yang diakui dan dihormati dalam sistem Pemerintahan Negara Kesatuan Republik Indonesia". Dalam penyelengaraan urusan rumah tangga desa, pemerintah desa mempunyai kewenangan untuk mengatur dan mengurus urusan-urusan atas inisiatif sendiri sesuai dengan keadaan dan kebutuhan yang diperlukan. Pemerintah desa mempunyai tanggung jawab untuk melaksanakan atau menentukan langkahlangkah yang akan dan harus ditempu dalam 
rangka kegiatan Pemerintahan dan Pembangunan di Desanya. Pembangunan di desa menjadi tanggung jawab Kepala desa sebagaimana diatur dalam Pasal 14 ayat (1) PP No 72 tahun 2005 ditegaskan bahwa Kepala Desa mempunyai tugas menyelenggarakan urusan pemerintahan, pembangunan, dan kemasyarakatan.

Untuk menggerakkan masyarakat dalam partisipasinya terhadap pembangunan, diperlukan adanya tenaga/unsur penggerak yang mampu menggerakkan dan mengarahkan kemampuan masyarakat untuk dapat mewujudkan cita-cita pembangunan dalam hubungan ini, maka kepala desa sebagai kepala pemerintahan memegang peranan yang menentukan. Sebagai pimpinan tertinggi dan penanggung jawab pelaksanaan pemerintahan dan pembangunan, ia harus mampu mengemban tugas yang dibebankan kepadanya yang saling kait-mengkait termasuk tugas pembangunan yang multi dimensional.

Oleh karena itu faktor kemampuan Kepala Desa selaku aparat pelaksana dan merupakan pemimpin formal di Desa mempunyai peranan yang sangat sentral yang dapat mempengaruhi terhadap keberhasilan pelaksanaan pembangunan di desanya. Karena dari kemampuan Kepala Desa yang memadai tersebut, akan memudahkan Kepala Desa yang bersangkutan di dalam mempengaruhi dan mengarahkan masyarakat untuk bekerjasama dalam mencapai tujuan yang diharapkan. Peranan Kepala Desa sangatlah menentukan bahkan menjadi kunci utama dapat tidaknya proses pembangunan itu berjalan secara baik dan lancar. Kehadirannya sangat diperlukan dalam menggerakkan partisipasi masyarakat dalam pembangunan di wilayahnya masing-masing, khususnya untuk pemerataan hasil-hasil pembangunan dengan menumbuhkan prakarsa serta menggerakkan swadaya gotong royong masyarakat dalam pembangunan.

Dalam hubungan ini pemerintah sesuai perundangan yang berlaku berkewajiban untuk memberikan bimbingan, pengarahan, pembicaraan dan bantuan dalam batas kemampuan yang tersedia disertai pengawasan yang intensif dan berkesinambungan.
Partisipasi masyarakat dalam pembangunan diwujudkan dalam bentuk prakarsa dan swadaya gotong royong masyarakat. Oleh karena itu, pendekatan dan prinsip-prinsip pembangunan desa adalah menyeluruh, terpadu dan terkoordinasi juga dinamis serta berkelanjutan dengan memperhatikan adanya keseimbangan kewajiban yang serasi antara kegiatan pemerintah dengan kegiatan masyarakat. Pembangunan desa merupakan gerakan pembangunan yang didasarkan atas prakarsa dan swadaya masyarakat. Pemerintah hanya memberikan stimulus yang bersifat perangsang untuk memancing swadaya masyarakat. Salah satu bentuk peran pemerintah desa adalah memberdayakan masyarakat. Pemberdayaan masyarakat antara lain dilakukan melalui peningkatan mutu atau kualitas pertanian salah satunya dengan pengadaan program UPPO. upaya peningkatan dan perbaikan kesuburan lahan pertanian melalui pengembangan usaha pengelolaan pupuk organik, dilaksanakan dengan cara pemberdayaan masyarakat, maka diharapkan dari kegiatan tersebut disamping dapat meningkatkan produksi tanaman pertanian, selanjutnya dapat meningkatkan pendapatan dan kesejahteraan petani serta mampu membuka lapangan kerja di pedesaan. Melalui program UPPO ini diharapkan masyarakat desa kolai mempu-nyai kemampuan untuk menghasilkan pupuk sendiri tanpa harus membeli pupuk lagi sehingga dapat meningkatkan kualitas pertanian dan taraf hidup masyarakat kolai.

Namun pada kenyataannya keberadaan UPPO ini tidak terlalu berpengaruh terhadap partisipasi masyarakat dalam pengelolaanya. Hal ini dikarenakan adanya beberapa kendalakendala, seperti penyediaan lahan untuk rumah kompos, lahan untuk bak fermentasi dan kandang ternak sapi yang harus disediakan sendiri oleh kelompok tani tanpa ganti rugi tanah dan juga kelompok tani harus menyediakan sendiri biaya operasional (bahan bakar, pelumas, honor operator, pemeliharaan ternak, penyediaan pakan ternak), semua dilakukan secara swadaya. Selain itu, terlihat juga masalah dengan pemanfaatan dan pengelolaannya yang kurang 
baik seperti pengelolaan dana yang tidak trasparan yang banyak di soroti masyarakat dan juga pembagian ternak sapi yang kurang merata. Memperhatikan berbagai hambatan, kendala dan kelemahan-kelemahan di atas, maka upaya yang dianggap sangat penting yaitu mendorong, meningkatkan, mengembangkan dan mengaktualisasikan kekuatan dan kemampuan yang bersumber di dalam masyarakat pedesaan itu sendiri. Melalui pemerintah desa di harapkan mampu menggerakkan dan mengarahkan kemampuan masyarakat secara partisipatif dalam pengelolaan program UPPO untuk mewujudkan atau ningkatkan taraf hidup masyarakat Kolai.

Penulis tertarik meneliti terhadap persoalan di atas dengan harapan hasil penelitian dapat memberikan hasil dan berguna bagi Desa Kolai Kecamatan Malua Kabupaten Enrekang.

\section{B. KERANGKA TEORITIS}

Istilah "peran" kerap diucapkan banyak orang. Sering kita mendengar kata peran dikaitkan dengan posisi atau kedudukan seseorang. Atau "peran" dikaitkan dengan "apa yang dimainkan" oleh seorang aktor dalam suatu drama. Mungkin tak banyak orang tahu, bahwa kata "peran", atau role dalam bahasa Inggrisnya, memang diambil dari dramaturgy atau seni teater. Dalam seni teater seorang aktor diberi peran yang harus dimainkan sesuai dengan plot-nya, dengan alur ceritanya, dengan lakonnya.

Istilah peran dalam "Kamus Besar Bahasa Indonesia" mempunyai arti pemain sandiwara (film), tukang lawak pada permainan makyong, perangkat tingkah yang diharapkan dimiliki oleh orang yang berkedudukan di masyarakat. Ketika istilah peran digunakan dalam lingkungan pekerjaan, maka seseorang yang diberi (atau mendapatkan) sesuatu posisi, juga diharapkan menjalankan perannya sesuai dengan apa yang diharapkan oleh pekerjaan tersebut. Karena itulah ada yang disebut dengan role expectation. Harapan mengenai peran seseorang dalam posisinya, dapat dibedakan atas harapan dari si pemberi tugas dan harapan dari orang yang menerima manfaat dari pekerjaan/posisi tersebut.

Peranan merupakan aspek dinamis dari kedudukan, yaitu seorang yang melaksanakan hak-hak dan kewajibannya. Artinya, apabila seseorang melaksanakan hak dan kewajibannya sesuai dengan kedudukannya, maka dia telah menjalankan suatu peranan. Suatu peranan paling tidak mencakup tiga hal berikut : Peranan meliputi norma-norma yang dihubungkan dengan posisi atau tempat seseorang dalam masyarakat, Peranan merupakan suatu konsep perihal apa yang dapat dilakukan oleh individu dalam masyarakat sebagai organisasi dan Peranan juga dapat dikatakan sebagai perilaku individu yang penting bagi struktur sosial.

Pemerintah Desa berdasarkan UndangUndang Nomor 32 tahun 2004 tentang Pemerintahan Daerah dimaknai sebagai kesatuan masyarakat hukum yang memiliki batas-batas wilayah yurisdiksi, berwenang untuk mengatur dan mengurus kepentingan masyarakat setempat berdasarkan asal-usul dan adat istiadat setempat yang diakui dan/ atau dibentuk dalam sistem pemerintahan nasional dan berada di kabupaten/kota, sebagaimana dimaksud dalam Undang-Undang Dasar Negara Republik Indonesia Tahun 1945. Landasan pemikiran dalam pengaturan mengenai pemerintah desa adalah keanekaragaman, partisipasi, otonomi asli, demokratisasi, dan pemberdayaan masyarakat. UndangUndang nomor 32 tahun 2004, megakui otonomi yang dimiliki oleh pemerintah desa ataupun dengan sebutan lainnya dan kepada desa melalui pemerintah desa dapat diberikan penugasan ataupun pendelegasian dari pemerintah ataupun pemerintah daerah untuk melaksanakan urusan pemerintahan tertentu. Sebagai perwujudan demokrasi sesuai dalam ketentuan UU No. 32 Tahun 2004 maka pemerintahan dalam tatanan pemerintah desa dibentuk Badan Permusya-waratan Desa (BPD) atau sebutan lain yang disesuaikan dengan budaya yang berkembang di desa bersangkutan, yang berfungsi sebagai lembaga pengatur dan pengontrol dalam penyelenggaraan pemerintah desa, seperti dalam pembuatan dan pelaksanaan Peratuan Desa, 
Anggaran Pendapatan dan Belanja Desa, dan Keputusan Kepala Desa. Di desa dibentuk lembaga kemasyarakatan yang berkedudukan sebagai mitra kerja pemerintah desa dalam memberdayakan masyarakat desa.

Dengan demikian pemerintah desa adalah kepala desa beserta perangkat desa dan anggota BPD. Kepala desa pada dasarnya bertanggung jawab kepada rakyat desa yang dalam tata cara dan prosedur pertanggungjawabannya disampaikan kepada bupati atau walikota melalui camat. Kepada Badan Permusyawaratan Desa, Kepala Desa wajib memberikan keterangan laporan pertanggungjawabannya dan kepada rakyat menyampaikan informasi pokokpokok pertanggungjawabannya namun tetap harus memberi peluang kepada masyarakat melalui Badan Permusyawaratan Desa untuk menanyakan dan/atau meminta keterangan lebih lanjut terhadap hal-hal yang bertalian dengan pertanggungjawaban dimaksud. Dan sesuai dengan Peraturan Pemerintahan Nomor 72 Tahun 2005 Bab IV pasal 11 pemerintah desa terdiri dari Pemerintah Desa dan BPD.

Menrut Sutardjo Kartodikusumo bahwa Desa adalah suatu kesatuan hukum di mana bertempat tinggal suatu masyarakat yang berkuasa mengadakan pemerintahan sendiri sedangkan R. Bintarto, Menurut tinjauan geografi yang dikemukakan, desa merupakan suatu hasil perwujudan geografis yang ditimbulkan oleh unsur-unsur fisiologis, sosial, ekonomi, politik, dan kultural yang terdapat di suatu daerah serta memiliki hubungan timbal balik dengan daerah lain.

Partisipasi masyarakat telah sekian lama diperbincangkan dan didengungkan dalam berbagai forum dan kesempatan. Intinya adalah agar masyarakat ikut serta dengan pemerintah memberi bantuan guna meningkatkan,memperlancar, mempercepat, dan menjamin berhasilnya usaha pembangunan. Maka secara umum partisipasi dapat diartikan sebagian "pengikutsertaan" atau pengambil bagian dalam kegiatan bersama. Partisipasi diartikan sebagai prakarsa, peran serta dan keterlibatan seluruh anggota masyarakat dalam pengambilan keputusan, perumusan rencana dan program pem- bangunan yang dibutuhkan masyarakat setempat, implementasi dan pemantauan serta pengawasannya, tidak lain dan tidak bukan adalah untuk meni-ngkatkan kesejahteraan masyarakat. Jadi partisipatif itu dimaksudkan sebagai suatu pendekatan pembangunan yang dilakukan dalam pembangunan pedesaan dan perkota-an, sering dikemukakan adanya pendekatan pembangunan desa terpadu dan pendekatan pembangunan desa berbasis kemandirian lokal.

Prakarsa dan peran serta secara aktif anggota masyarakat berarti pelibatan anggota masyarakat dalam berbagai kegiatan pembangunan masyarakat. Kegiatan partisipasi masyarakat dalam pembangunan meliputi identifikasi potensi, permasalahan yang dihadapi masyarakat, penyusunan programprogram pembangunan yang benar-benar dibutuhkan masyarakat lokal, implementasi program pembangunan dan pengawasannya. Partisipasi masyarakat dalam pembangunan yang diarahkan dan dilakukan dalam lingkungan masyarakat pedesaan setempat berarti orientasi pembangunan adalah ke dalam, karena anggota masyarakat dianggap sebagai pihak yang paling mengetahui potensi dan kondisi masyarakatnya.

Partisipatif dapat pula digunakan atau diterapkan sebagai strategi kebijakan untuk mencapai tujuan dan sasaran pembangunan yang telah ditetapkan yaitu untuk meningkatkan kesejahteraan masyarakat. Partisipatif sebagai pendekatan berarti sebagai suatu metoda yang digunakan untuk mengenal lebih dekat dan menganalisis lebih tepat, sedangkan partisipatif sebagai strategi kebijakan diartikan cara bagaimana mencapai tujuan dan sasaran yang telah ditetapkan. Partisipasi sebagai suatu pendekatan dan partisipasi sebagai suatu strategi kebijakan, keduaduanya adalah perlu diterapkan dan dilaksanakan, agar supaya segala sesuatu yang dihadapi dapat dikenali secara jelas dan penganalisaannya dapat dilakukan secara tepat, dan selanjutnya dapat ditentukan cara bagaimana pemecahannya dan tindakan pencapaian tujuan dan sasarannya dilakukan secara tepat dan terarah sesuai kebutuhan masyarakat. 
Secara umum ada 2 jenis definisi partisipasi yang beredar di masyarakat, menurut Soetrisno (1995:221), yaitu:

1. Partisipasi rakyat dalam pembangunan sebagai dukungan masyarakat terhadap rencana/proyek pembangunan yang dirancang dan ditentukan tujuan oleh perencana. Ukuran tinggi rendahnya partisipasi masyarakat dalam defenisi ini pun diukur dengan kemauan masyarakat ikut menanggung biaya pembangunan, baik berupa uang maupun tenaga dalam melaksanakan pembangunan.

2. Partisipasi masyarakat dalam pembangunan merupakan kerja sama erat antara perencana dan masyarakat dalam merencanakan, melaksanakan, melestarikan dan mengembangkan hasil pembangunan yang telah dicapai. Ukuran tinggi dan rendahnya partisipasi masyarakat dalam pembangunan tidak hanya diukur dengan kemauan masyarakat untuk menanggung biaya pembangunan, tetapi juga dengan ada tidaknya hak masyarakat untuk ikut menentukan arah dan tujuan proyek yang akan dibangun di wilayah mereka. Ukuran lain yang dapat digunakan adalah ada tidaknya kemauan masyarakat untuk secara mandiri melestarikan dan mengembangkan hasil proyek itu.

Secara etimologi istilah pengelolaan berasal dari kata "kelola" (to manage) dan biasanya merujuk pada proses mengurus atau menangani sesuatu untuk mencapai tujuan tertentu (Nugroho, 2003: 119). Banyak ahli yang memberikan pengertian tentang pengelolaan yang berbeda-beda dalam pengkajiaannya, namun pada prinsipnya memiliki maksud dan tujuan yang sama, yakni untuk mencapai tujuan suatu organisasi. Pengelolaan merupakan suatu tindakan yang berupaya menata setiap pelaksanaan tugas terutama tugas-tugas pokok menuju suatu keteraturan yang baik dan saling berhubungan. Dengan adanya pengelolaan diharapkan dapat merubah suatu keadaan hingga menjadi lebih baik dari keadaan sebelumnya, dan bahkan dapat menjadi suatu yang baru, sehingga memiliki nilai-nilai yang lebih baik dari keadaan sebelumnya. Pengelolaan juga mengandung makna sebagi pembaharuan, yaitu melakukan usaha-usaha untuk membuat sesuatu menjadi lebih sesuai atau cocok dengan kebutuhan menjadi lebih baik dan lebih bermanfaat. (Pamudji, 1985: 7).

Dari pengertian tersebut terlihat bahwa pengelolaan selalu didasari atas usaha untuk menjadikan sesuatu menjadi lebih bermanfaat dan faktor penting yang terdapat didalamnya adalah mengubah sesuatu menjadi baru atau memiliki nilai tinggi. Disamping itu pengelolaan sebagai pembaharuan dalam arti menjaga keseimbangan akibat tekanan-tekanan perubahan dan memelihranya agar cocok dengan kebutuhan yang lebih bermanfaat. Pengelolaan juga mencakup beberapa kegiatan yang saling berhubungan sehingga membentuk suatu sistem kegiatan yang bekerja menurut proses atau aturan yang berlaku. Adapun unsur-unsur kegiatan yang dimakasud adalah perencanaan, pengaturan atau prosedur pengawasan seperti yang dikemukakan oleh Wirasapoetra (1979: 21) yaitu pengelolaan adalah suatu proses atau pengembang yang mencakup urutan pengertian dan diawali dengan demikian, menumbuhkan, memelihara pertumbuhan tersebut yang disertai dengan usaha-usaha perbaikan, penyempurnaan dan akhirnya mengembangkannya.

Pengertian tersebut menekankan pengelolaan merupakan suatu rangkaian tindakan perencanaan, karena perencanaan memegang peranan penting. Dengan adanya perencanaan yang baik tindakan pengelolaan akan memperoleh hasil yang optimal. Tidak sedikit orang yang mengartikan pengelolaan sama dengan arti manajemen. Karena antara manajemen dan pengelolaan memiliki tujuan yang sama yaitu tercapainya tujuan organisasi lembaga.

Pengelolaan merupakan sebuah bentuk bekerja dengan orang-orang secara pribadi dan kelompok demi tercapainya tujuan organisasi lembaga. satu yang perlu diingat bahwa pengelolaan berbeda dengan kepemimpinan. Bila pengelolaan terjadi bila terdapat kerjasama dengan orang pribadi maupun kelompok, maka seorang pemimpin bisa mencapai tujuan yang diharapkan tanpa perlu menjadi seorang manajer yang efektif. 
Menurut Widjaja (1987: 53) dikemukakan bahwa setiap kegiatan yang mempunyai tujuan dan sasaran yang sifatnya terarah dan khusus disebut program. Sedangkan menurut Hasibuan (2001: 100) Program adalah suatau rencana yang pada dasarnya telah menggambarkan rencana yang konkret. Rencana ini konkret, karena dalam program sudah tercantum baik sasaran, kebijaksanaan, prosedur,waktu maupun anggarannya. Jadi program juga merupakan usaha-usaha untuk mengefektifkan rangkaian tindakan yang harus dilaksanakan menurut bidangnya masing-masing.

Program merupakan jaringan yang kompleks yang terdiri dari tujuan, kebijakan, prosedur, aturan, penugasan, langkah yang harus dilakukan, alokasi sumber daya dan elemen lain yang harus dilakukan berdasarkan alternatif tindakan yang dipilih. Biasanya modal dan anggaran dipakai untuk mendukung program. (Hanafi, 1997: 126). Sedangkan dalam UU Nomor 25 Tahun 2004 tentang SPPN bahwa "Program adalah bentuk instrumen kebijakan yang berisi satu atau lebih kegiatan yang dilaksanakan oleh instansi pemerintah/lembaga atau masyarakat yang dikoordinasikan oleh instansi pemerintah untuk mencapai sasaran dan tujuan serta memperoleh alokasi anggaran".

Di dalam program terdapat rencanarencana jangka panjang atau pendek, rencana orientasi, rencana operasional, sasaransasaran kebijaksanaan dan prosedurprosedur. Namun demikian, istilah program digunakan secara berlainan di dalam literatur tentang perencanaan manajemen. Akuntabilitas program berkaitan dengan pertimbangan apakah tujuan yang ditetapkan dapat dicapai atau tidak, dan apakah organisasi telah mempertimbangkan alternatif program yang memberikan hasil yang optimal dengan biaya yang minimal. Lembaga-lembaga publik harus mempertanggungjawabkan program yang telah dibuat sampai pada pelaksanaan program. Dengan kata lain akuntabilitas program berarti bahwa program-program organisasi hendaknya merupakan program yang bermutu yang mendukung strategi dan pencapaian visi, misi, dan tujuan organisasi.
Program UPPO adalah bantuan sosial yang di keluarkan oleh Menteri Pertanian melalui Direktorat Jenderal Prasarana dan Sarana Pertanian Tahun Aggaran 2011 (Ditjen PSP Ta.2011). Sasaran dari program UPPO adalah sentra produksi tanaman pangan, holtikultura, perkebunan rakyat dan sentra peternakan, sebanyak 950 unit yang tersebar di 276 kabupaten di 32 propinsi. Adapun tujuan dari program UPPO yaitu : Menyediakan fasilitas terpadu pengolahan bahan organik (jerami, sisa naman, limbah ternak, sampah organik) menjadi kompos (pupuk organik). Memenuhi kebutuhan pupuk organik oleh, dari dan untuk petani, tanpa harus membeli dan bergantung kepada pabrik pupuk, Mensubstitusi kebutuhan pupuk anorganik, Memperbaiki kesuburan dan produktivitas lahan pertanian, Meningkatkan populasi ternak, Membuka kesempatan berusaha dan lapangan kerja di pedesaan, Media pelatihan dan penelitian bagi berbagai kalangan masyarakat, termasuk petani, mahasiswa dan karyawan, Melestarikan sumber daya lahan pertanian dan lingkungan.

Perbaikan kesuburan lahan dengan penggunan pupuk organik perlu terus dikembangkan untuk meningkatkan kualitas dan nilai tambah produk pertanian, efisiensi dalam usaha tani, peningkatan aspek kesehatan serta terpeliharanya lingkungan hidup. Proses pembuatan pupuk organik dari bahan baku berupa limbah panen dan limbah peternakan apabila dilakukan secara alami memerlukan waktu cukup lama yaitu sekitar 1-2 bulan bahkan lebih. Apabila proses tersebut menggunakan alat bantu berupa APPO (alat pengolah pupuk organik) yang berfungsi sebagai pencacah dan penghancur bahan organik, maka waktu pengomposan menjadi lebih pendek yaitu sekitar hanya 2-3 minggu. Dalam skala kelompok tani/gapoktan, diperlukan Usaha Pengelolaan Pupuk Organik (UPPO), yaitu berupa bangunan rumah kompos untuk penempatan mesin APPO, bak fermentasi, dilengkapi alat pengangkut kendaraan bermotor roda tiga agar lebih efisien, serta hewan ternak untuk memenuhi kebutuhan bahan baku pupuk organik. Lokasi penempatan UPPO diupayakan berada di 
dekat sumber limbah panen di sentra produksi tanaman, sentra peternakan, sehing-ga ketersediaan bahan baku pembuatan pupuk organik lebih terjamin. Oleh karena itu, penyediaan ternak sapi/kerbau dalam paket kegiatan pengembangan UPPO sangat mendukung tersedianya bahan baku tersebut.

Upaya peningkatan dan perbaikan kesuburan lahan pertanian melalui pengembangan unit pengolah pupuk organik, dilaksanakan dengan cara pemberdayaan masyarakat, maka diharapkan dari kegiatan tersebut disamping dapat meningkatkan produksi tanaman pertanian, selanjutnya dapat meningkatkan pendapatan dan kesejahteraan petani serta mampu membuka lapangan kerja di pedesaan.

Good governance adalah suatu penyelenggaraan negara yang mengarah kepada tujuan yang baik melalui perumusan kebijakan yang berhubungan dengan masalah-masalah sosial dan sistem nilai dalam operasi organisasi, yang berlaku bagi semua orang di bawah sistem demokrasi (soelendro, 2000). Menurut Ibnu Rubiyanto 2001), dari segi aspek fungsi, governance dapat ditinjau dari apakah pemerintah telah berfungsi secara efektif dan efisien dalam upaya mencapai tujuan yang telah digariskan, atau sebaliknya. Pemerintahan Desa adalah penyelenggaraan urusan pemerintahan oleh Pemerintah Desa dan Badan Permusyawaratan Desa dalam mengatur dan mengurus kepentingan masyarakat setempat berdasarkan asal-usul dan adat istiadat setempat yang diakui dan dihormati dalam sistem Pemerintahan Negara Kesatuan Republik Indonesia. Pemerintah desa diselenggarakan di bawah pimpinan seorang kepala desa beserta perangkat desa, mewakili masyarakat desa guna hubungan ke luar maupun ke dalam masyarakat yang bersangkutan". Pemerintah Desa mempunyai tugas membina kehidupan masyarakat desa, membina perekonomian desa, memelihara ketentraman dan ketertiban masyarakat desa. Dengan adanya program UPPO diharapkan kemudian peran pemerintah desa sebagai pemimpin, pembina, pengayom dan pelayan masyarakat dapat di implementasikan untuk mendorong partisipasi masyarakat dalam hal pengelolaan UPPO.

\section{METODE PENELITIAN}

Penelitian ini dilaksanakan di Desa Kolai Kecamatan Malua Kabupaten Enrekang dengan alasan bahwa desa kolai adalah salah satu desa yang menjalankan program UPPO (usaha pengelolaaan pupuk organik) dan juga merupakan tempat tinggal saya. Tipe dan Dasar Penelitian yang digunakan adalah tipe deskriptif kuantitatif, yaitu penelitian yang bertujuan memberikan gambaran secara lengkap mengenai masalah yang diteliti, berkenaan dengan bagaimana peran pemerintah desa dalam pengelolaan program pupuk organik di Desa Kolai sedangkan Dasar penelitian yang digunakan adalah survey yaitu metode pengumpulan data melalui daftar pertanyaan dari sejumlah informan dan responden yang di anggap mewakili seluruh populasi. Populasi adalah wilayah generalisasi yang terdiri atas objek/subyek yang mempunyai kualitas dan karakteristik tertentu yang ditetapkan oleh peneliti untuk dipelajari dan kemudian ditarik kesimpulannya. Berhubung karena penelitian ini saya lakukan di desa Kolai maka yang menjadi populasi dalam penelitian ini adalah semua aparatur desa dan masyarakat di Desa Kolai sebanyak 80 orang. Pengambilan sample dimaksudkan sebagai representative dari seluruh populasi. Sehingga kesimpulannya juga berlaku bagi keselurahan populasi. Dengan kata lain sample adalah bagian dari populasi. Jadi karena keterbatasan waktu, tenaga dan biaya sehing-ga tidak dapat mengambil sampel yang besar maka sampel yang digunakan adalah: Informan : Kepala desa 1 orang, Ketua penge-lola program UPPO 1 orang, Tokoh masyara-kat 2 orang, Penyuluh UPPO dari Dinas Pertanian Kab. Enrekang 1 orang. Responden : Masyarakat yang terlibat dalam pengelolaan UPPO sebanyak 30 orang. Jadi jumlah informan secara keseluruhan adalah 5 orang dan jumlah responden sebanyak 30 orang. Teknik penentuan sampel menggunakan teknik purposive sampling dimana ditentukan oleh peneliti sendiri sesuai dengan kebutuhan. Jadi sampel ini adalah untuk mengetahui pengelolaan program UPPO (Usaha Penge-lolaan Pupuk Organik) terhadap objek yang sedang diteliti yakni pihak yang 
terkait dengan pengelolaan Program UPPO (Usaha Pengelolaan Pupuk Organik) dalam hal ini adalah pemerintah desa. Teknik pengumpulan data yang digunakan dalam penelitian ini adalah :Wawancara, Observasi dan Kuesioner. Jenis data yang digunakan dalam penelitian ini adalah : Data Kualitatif adalah data yang tidak berbentuk angka, tetapi cukup menggam-barkan suatu keadaan yang berhubungan dengan Peran Pemerintah Desa dalam Pengelolaan Program UPPO (usaha pengelola-an pupuk organik) di Desa Kolai Kec. Malua Kab. Enrekang dan Data Kuantitatif yaitu data yang diperoleh dalam bentuk angkaangka. Sumber data yang digunakan dalam penelitian ini adalah: Data primer adalah data yang dipe-roleh secara langsung dari responden dan informan. Pengumpulan data dilakukan secara observasi langsung, wawancara dan kuesio-ner dan Data sekunder adalah data yang dipe-roleh melalui beberapa data yang tersedia sesuai dengan judul penelitian yang sifatnya melengkapi data primer, seperti laporan dan dokumen yang bersifat informasi tertulis ang digunakan dalam penelitian. Penelitian ini menggunakan analisis secara kualitatif dan bantuan data kuantitatif dengan menggu-nakan tabulasi frekuensi dari data atau jawaban kuesioner.

\section{HASIL DAN PEMBAHASAN}

\section{PERAN PEMERINTAH DESA DALAM PENGELOLAAN PROGRAM UPPO DI DESA KOLAI}

Telah dijelaskan pada bab sebelumnya bahwa pemerintah desa atau disebut dengan nama lain adalah kepala desa dan perangkat desa sebagai unsur penyelengara pemerintah desa. Sedangkan kepala desa adalah orang yang mempunyai peran dan juga kedudukan yang sangat penting dalam pemerintahan desa. Kepala desa merupakan pemimpin terhadap jalannya tata urusan pemerintahan, penyelengara dan sekaligus sebagai penaggung jawab atas jalannya roda pemerintahan dan pembangunan di dalam wilayahnya. Pemerintah desa merupakan pemegang kendali dalam pembangunan di wilayah pedesaan.
Oleh karena itu kepala desa beserta jajarannya merupakan penanggung jawab atas jalannya roda pemerintahan dan roda pembangunan sehingga maju mundurnya pembangunan di pedesaan tergantung dari peran pemerintah desa dalam mempengaruhi masyarakatnya untuk turut serta di dalam pembangunan. Pemerintah desa mempunyai peranan yang sangat berpengaruh terutama dalam upayanya untuk menciptakan iklim yang mendorong tumbuhnya prakarsa dan swadaya masyarakat di pedesaan, yang dilakukan dengan penyampaian pesan-pesan pembangunan, pengarahan kepada masyarakat untuk berpartisipasi dalam pembangunan dan penyaluran aspirasi masyarakat. Partisipatif masyarakat desa diwujudkan dalam bentuk pengerahan dan pemanfaatan dana dan daya yang ada dalam masyarakat untuk meningkatkan kegiatan pembangunan di daerah pedesaan.

\section{Peran Pemerintah Desa dalam} memfasilitasi pengadaan program UPPO.

Tanggapan responden mengenai peran pemerintah desa dalam memfasilitasi pengadaan program UPPO sangat berperan sangat karena tanpa bantuan pemerintah desa maka pengadaan program UPPO tidak akan berjalan lancar.

Sehubungan dengan penjelasan di atas, berikut hasil wawancara yang diungkapkan oleh bapak Syukur, S.iP Kepala Desa Kolai, menyatakan:

"Dalam hal pengadaan program UPPO, kami sebagai pemerintah desa sangat mendukung program ini dan saya sebagai kepala desa akan berusaha meningkatkan partisipasi masyarakat dalam pengelolaan UPPO dengan memfasilitasi segala kebutuhan masyarakat dalam kaitannya dengan pengelolaan UPPO (wawancara desember 2012)".

Sesuai dengan apa yang di ungkapkan kepala desa kolai bahwasanya peran pemerintah desa dalam pengadaan program UPPO sangat berpengaruh, tidak hanya mendukung pemerintah desa juga berusaha memfasilitasi segala kebutuhan masyarakat pengelola UPPO. tanggapan responden 
mengenai manfaat program UPPO yaitu sangat sangat bermanfaat karna mayoritas pekerjaan warga kolai adalah petani jadi sangat cocok dengan program ini. Tanggapan responden mengenai keterlibatan warga masyarakat dalam pengelolaan UPPO yaitu kurang terlibat dalam pengelolaan UPPO karena ada beberapa responden yang disibukkan dengan pekerjaan lain sehingga tidak bisa memfokuskan diri dalam pengelolaan UPPO sedangkan tanggapan responden mengenai program UPPO, apakah sudah sesuai dengan kebutuhan masyarakat yaitu sangat sesuai karena dengan program ini maka kebutuhan pupuk petani dapat terpenuhi.

Sejalan dengan hal tersebut diatas, maka berdasarkan hasil wawancara dengan penyuluh UPPO dari dinas pertanian yang mengatakan:

"Program UPPO ini sangat besar manfaatnya jika di kelola dengan baik, karena tujuan program ini adalah untuk memenuhi kebutuhan pupuk organik bagi petani tanpa harus membeli pupuk lagi, memperbaiki kesuburan lahan pertanian dan masih banyak manfaat lainnya. Kalau saya melihat desa kolai adalah tempat yang cocok untuk program ini karena sebagian besar masyarakat kolai bekerja sebagai petani maka secara otomatis masyarakat akan butuh pupuk (wawancara IS desember 2012)"

Hal diatas menunjukkan betapa besar manfaat dari UPPO ini, sebagaimana tanggapan responden yang umumnya mengatakan program ini sangat bermanfaat dan sesuai dengan kebutuhan masyarakat. Kegiatan memberi contoh atau lebih dikenal dengan keteladanan merupakan unsur yang memegang peranan penting dan sangat menentukan bagi berhasilnya seorang pemimpin dalam melaksanakan fungsi dan tugas bawahan/orang yang dipimpin sehingga dapat mengikuti apa yang dikehendakinya dalam pelaksanaan tugas. Hal ini dapat kita lihat dari peran kepala desa sebagai fasilitator, memfasilitasi pengadaan program UPPO.

\section{Peran Pemerintah Desa Dalam Mem-} fasilitasi Setiap Pertemuan Utusan Dari Dinas Pertanian Dengan Kelompok Tani
Tanggapan responden mengenai peran pemerintah desa dalam memfasilitasi setiap pertemuan utusan dinas pertanian dengan pengelola UPPO yaitu sangat berperan karena setiap akan diadakan pertemuan pak desa yang selalu menyediakan tempat pertemuan dan selalu menginformasikan ke masyarakat bahwa akan diadakan pertemuan. Tanggapan responden mengenai peran pemerintah desa untuk memberikan saran/ide-ide dalam setiap pertemuan pengelola UPPO yaitu Alasan responden mengatakan berperan karena kepala desa kolai sering memberikan saran/ide-ide dalam pertemuan pengelola UPPO. Tanggapan responden mengenai peran pemerintah desa dalam mendukung keputusan yang ditetapkan pada setiap pertemuan pengelola UPPO yaitu sangat berperan karena pemerintah desa selalu mendukung setiap keputusan yang di tetapkan dalam pertemuan pengelola UPPO.

Dari uraian diatas dapat disimpulkan bahwa pemerintah desa menaruh perhatian yang besar terhadap UPPO terbukti dengan tanggapan responden mengenai apa yang dilakukan pemerintah desa yang selalu memfasilitasi pertemuan UPPO, selain itu dari tanggapan responden pemerintah desa juga sering mengikuti pertemuan UPPO, sering memberikan saran/ide-ide dan mendukung keputusan-keputusan hasil pertemuan. Hal ini senada dengan hasil wawancara dengan ketua pengelola UPPO yang mengatakan:

"Selama ini pemerintah desa memang sangat mendukung adanya program ini, salah satu bentuk dukungannya yaitu memfasilitasi pengadaan program UPPO dengan mengurusi persuratan atau administrasinya selain itu pemerintah desa juga memfasilitasi dalam pertemuan utusan dinas pertanian dengan pengelola UPPO dengan memberikan informasi dan menyediakan tempat pertemuan" (wawancara, L.ST desember 2012)".

Tanggapan responden mengenai peran kepemimpinan kepala desa untuk menumbuhkan partisipasi masyarakat dalam pengelolaan UPPO yaitu lebih berpartisipasi apabila kepala desa dapat memperlihatkan teladan yang baik dalam masyarakat. Sedangkan responden yang menjawab kurang 
berperan karena menurutnya kepemimpinan kepala desa saat ini kurang baik.

Hal di atas senada dengan hasil wawancara dengan salah satu tokoh masyarakat yang juga ketua LKSMD yang mengatakan :

"Untuk meningkatkan partisipasi masyarakat memang dibutuhkan peran pemerintah desa terutama kepala desa dalam mempengaruhi, mendorong dan meningkatkan semangat masyarakat dalam berpartisipasi untuk pengelolaan UPPO. Dan saya melihat sejauh ini pemerintah desa telah memberikan dukungan dan bantuannya terutama kepala desa walaupun tidak sepenuhnya aparatur desa aktif melibatkan diri dalam program ini, karena saya melihat selama ini yang selalu perhatian terhadap UPPO ini hanyalah kepala desa saja" (wawancara, D. Jldn desember 2012).

Peranan pemerintah desa sebagai fasilitator masyarakat dapat mendorong proses pembangunan ke arah lebih baik dengan memanfaatkan kondisi sektor perekonomian di bidang pertanian menjadi lebih baik dari sebelumnya sehingga berimbas kepada kehidupan masyarakat yang sejahtera.

\section{Peran Pemerintah Desa Dalam Melakukan Pembinaan.}

Tanggapan responden mengenai peran pemerintah desa dalam memberikan dorongan semangat bagi pengelola UPPO yaitu sangat berperan karena dukungan yang diberikan pemerintah desa dapat menambah semangat masyarakat untuk mengelola UPPO. Tanggapan responden mengenai peran pemerintah desa dalam memberi dana/materi yaitu sangat berperan karena dengan bantuan dana yang diberikan pemerintah desa itu dapat memancing dan menumbuhkan swadaya masyarakat untuk berpartisipasi dalam pengelolaan UPPO. Tanggapan responden mengenai peran pemerintah desa dalam memberi bantuan fisik/tenaga kerja yaitu tidak berperan karena tidak ada satupun aparat desa yang pernah ikut dalam kegiatan sehari-hari pengelola UPPO atau tidak pernah ikut membantu dalam pengelolaanya. Tanggapan responden mengenai peran pemerintah desa dalam memberi bantuan non fisik (ide/pemikiran) yaitu berperan karena melalui bantuan ide dan pemikiran pemerintah desalah sehingga pengelola UPPO dapat mengambil keputusan dengan baik dan benar.

Dari pernyataan-pernyataan di atas, bahwa pemerintah desa sangat membantu dalam kelancaran pengelolaan UPPO dimana pemerintah desa sesuai tanggapan responden pernah memberikan bantuan dalam bentuk dana/materi. Dana yang dimaksud di sini adalah pemberian sejumlah uang untuk membantu kelompok tani dalam menyediakan dana awal dan juga untuk memancing swadaya masyarakat untuk turut berpartisipasi dalam pengelolaan UPPO. Selain itu, pemerintah desa juga sering memberikan bantuan dalam bentuk non fisik (ide/pemikiran) seperti tanggapan yang dikemukakan oleh responden.

Hal di atas senada dengan hasil wawancara dengan salah satu tokoh masyarakat yang juga ketua BPD mengatakan.

"Menurut saya, pengaruh pembinaan yang dilakukan oleh kepala desa sangat besar terhadap partisipasi masyarakat dalam hal pengelolaan UPPO. Dengan dukungan dan adanya bantuan dari pemerintah desa itu sangat membantu dalam meningkatkan semangat dan partisipasi masyarakat dalam pengelolaan UPPO" (wawancara, M.S desember 2012)".

Pemerintah desa sadar dan mengerti tentang pentingnya pembinaan masyarakat. Seperti yang termaktub dalam Peraturan Pemerintah Nomor 72 Tahun 2005 tentang Pedoman Umum Penyelenggaraan Pemerintahan Desa yaitu membina kehidupan masyarakat dan membina perekonomian. Dalam hubungannya dengan pembinaan, Taliziduhu Ndraha (1991), mengungkapkan bahwa yang menjadi sasaran pembinaan khususnya dalam pembinaan masyarakat adalah mentalitasnya. Mentalitas yang belum sadar harus dibangunkan, yang tidak sesuai dengan pembangunan harus dirubah, yang belum beres harus ditertibkan dan yang masih kosong harus diisi.

Dari berbagai pernyataan di atas dapat disimpulkan bahwa peranan pemerintah desa sebagi pembina masyarakat dapat mendo- 
rong proses pembangunan ke arah lebih baik. Aktivitas pembinaan yang dilaksanakan oleh pemerintah desa lebih bersifat penjelasan akan makna, maksud, tujuan, dan manfaat dari pelaksanaan pembangunan. Melalui pembinaan inilah dibangkitkan semangat dan kemauan serta ditumbuhkan jiwa membangun dalam diri warga masyarakat kolai.

\section{E. KESIMPULAN}

Peran Pemerintah Desa Dalam Pengelolaan Program UPPO, ada beberapa hal yang menjadi kesimpulan yaitu dukungan aparatur pemerintah desa dalam pengelolaan program UPPO di desa kolai sangat berpengaruh, dimana dapat kita lihat dari adanya upaya aparat desa untuk meningkatkan partisipasi masyarakat dalam pengelolaan UPPO. Salah satu upaya yang dilakukan pemerintah desa dalam meningkatkan partisipasi masyarakat dalam pengelolaan UPPO yaitu dengan memfasilitasi kebutuhan masyarakat berkenaan dengan pengelolaan UPPO dan pemerintah juga sedikit membantu dalam hal materi.

Hal ini menunjukkan bahwa adanya dukungan dan bantuan dari pemerintah desa sangat berpengaruh terhadap semangat masyarakat untuk berpartisipasi dalam pengelolaan UPPO. Dari hasil penelitian juga di simpulkan bahwa pemerintah desa hanya bisa mendukung, mendorong, memfasilitasi serta mendampingi dalam pengelolaan UPPO. Dalam usaha untuk mensejahterakan masyarakat pemerintah desa kolai bisa dikatakan telah sedikit memuaskan warganya karena dengan bantuan pemerintah desa sehingga pengadaan program UPPO dapat berjalan atau terlaksana dengan lancar. Keberadaan pemerintah desa sangat berpengaruh terlihat dengan apa yang diberikan oleh pemerintah desa kolai kepada masyarakat dalam hal ini yang terkait dengan program UPPO, serta bagaimana kepala desa menyelesaikan masalah yang dihadapi masyarakat dan lainnya yang menjadi kebutuhan atau kepentingan masyarakat. Jadi dapat kita saksikan betapa aparat pemerintah desa berperan aktif dalam mengayomi masyarakat walaupun belum optimal. Belum optimalnya peran pemerintah desa dikarenakan tidak semuanya aparat desa terlibat dalam hal pengelolaan UPPO. Melalui pembinaan inilah dibangkitkan semangat dan kemauan serta ditumbuhkan jiwa membangun dalam diri warga masyarakat desa Kolai.

\section{DAFTAR PUSTAKA}

Adisasmita, Rahardjo. 2006. Membangun Desa Partisipatif. Edisi Pertama. Yogyakarta: Graha Ilmu.

Arikunto, Suharsimi. 1996. Prosedur Penelitian. Surabaya: Airlangga.

Brata, I Nyoman, 1982, Masyarakat Desa dan Pembangunan Desa, Jakarta : Ghalia Indonesia.

Kementerian Pertanian, 2011. Pedoman Teknis Pengembangan Usaha Pengelolaan Pupuk Organik (UPPO), Direktorat Jenderal Prasarana dan Sarana Pertanian, Direktorat Perluasan dan Pengelolaan Lahan.

Labolo, Muhadam. 2010. Memahami Ilmu Pemerintahan: Suatu Kajian, Teori, Konsep, dan Perkembangannya. Edisi ketiga. Jakarta: Rajawali Pers

Mareng, Rahman, 2012. Demokratisasi Pembangunan Desa (StudI Kasus Desa Nggolombay Kecamatan Aesesa Kabupaten Nagekeo Provinsi Nusa Tenggara Timur), Skripsi, (Tidak Dipublikasikan) Program Studi Ilmu Pemerintahan FISIP Unismuh Makassar

Pusat Info Data Indonesia (PIDI). 2007. Peraturan tentang Desa dan Kelurahan, Jakarta: Pusat Data Info Indonesia.

Sumaryadi, Nyoman. 2005, Perencanaan Pembangunan Daerah Otonom dan Pemberdayaan Masyarakat, Jakarta : Citra Utama 
Syarifin Pipin, UU No.32 Tahun 2004 dan Pemerintahan Desa.

Soemantri, Bambang Trisantono. 2011. http://id.shvoong.com/social-sciences/politiPedoman Penyelenggaraan Pemerintahan Desa. Bandung: Fokus Media.

Sugiyono, 2005, Metode Penelitian Kualitatif, Bandung: Alfabeta

Usman, Sunyoto, 2003. Pembangunan dan Pemberdayaan Masyarakat, Yogyakarta: Pustaka Pelajar,

Undang-undang Nomor 25 Tahun 2004 tentang Sistem Perencanaan Pembangunan Nasional (SPPN).

Wijaya, HAW, 2010. Otonomi Desa Merupakan Otonomi Yang Asli, Bulat Dan Utuh. Edisi Pertama. Jakarta: Rajawali Pers.

\section{WEBSITE}

http://id.shvoong.com/social-sciences/education/2113811-pengertian-kinerja

http://bayuonvixion.wordpress.com/2011/ $04 / 11 /$ pengertian-pemerintah danpemerintahan/.

http://rimaru.web.id/pengertian-kinerjamenurut-pendapat-para-ahli/ http://carapedia.com/pengertian_definisi_ desa_info2128.html. cal-science/2166427 pengertian pemerintah/\# ixzz1x7cTjU5L

http://carapedia.com/pengertian_definisi_ pengelolaan_info2163.html

http://publik.brawijaya.ac.id/simple/us/ jurnal/pdffile/Annisa\%20partisipasi $\% 20$ politik 20dalam\%20pembangu nan\%20desa.pdf, 13 Desember 2008).

\section{DOKUMEN DAN SUMBER LAINNYA}

Undang - Undang Dasar 1945.

Peraturan Pemerintah Republik Indonesia Nomor 72 Tahun 2005 tentang Desa.

Undang-Undang Nomor 25 Tahun 2004 Tentang Sistem Perencanaan Pembangunan Nasional.

Undang-undang Republik Indonesia Nomor 32 Tahun 2004 Tentang Pemerintahan Daerah.

Undang-Undang Republik Indonesia Nomor 22 Tahun 1999 tentang Pemerintahan Daerah 